\title{
USER EMBRACEMENT AS A GOOD PRACTICE IN PRIMARY HEALTH CARE
}

\author{
Patricia Guerrero ${ }^{1}$, Ana Lúcia Schaefer Ferreira de Mello², Selma Regina de Andrade ${ }^{3}$, Alacoque Lorenzini \\ Erdmann $^{4}$
}

${ }^{1}$ Ph.D. in Education. CNPq post-doctoral fellow. Santa Catarina, Brazil. E-mail: paguerrero@ig.com.br

${ }^{2}$ Ph.D. in Nursing and Collective Health Dentistry. Professor of the Department of Dentistry at Federal University of Santa Catarina (UFSC). Santa Catarina, Brazil. E-mail: alfm@terra.com.br

${ }^{3}$ Ph.D. in Nursing. Professor of the Department of Nursing and the Graduate Program in Nursing at UFSC. Santa Catarina, Brazil. E-mail: selma@ccs.ufsc.br

${ }^{4}$ Ph.D. in Nursing Philosophy. Full Professor of the Department of Nursing and the Graduate Program in Nursing at UFSC. CNPq Researcher 1A. Santa Catarina, Brazil. E-mail: alacoque@newsite.com.br

\begin{abstract}
The purpose of this study was to understand user embracement as a good practice for use in primary health care, according to the perceptions of administrators, health professionals and patients, considering the dimensions of dialogue, attitude and reorganization of health services. It consists of a descriptive-analytical investigation, of a qualitative nature. The Grounded Theory was used as the theoretical-methodological referential. Data were obtained through interviews performed with seven coordinators, ten professionals and twelve patients of the Health Centers of Florianópolis-SC. Under the perspective of good practices, user embracement becomes a point of intersection between different subjects and primary health care practices, unfolding the dimensions of embracementdialogue, embracement-attitude and embracement-reorganization of services. User embracement triggers transformations in the working process, in the relationships established in the care spaces and in the organizational scope of the services. The interconnection of this triad reconfigures and changes the actions in primary health care and contributes to the consolidation of this health care model. DESCRIPTORS: User embracement. Primary health care. Public health practice. Unified Health System.
\end{abstract}

\section{O ACOLHIMENTO COMO BOA PRÁTICA NA ATENÇÃO BÁSICA À SAÚDE}

RESUMO: Objetivou-se compreender o acolhimento como boa prática de saúde desenvolvida na atenção básica, na percepção de gestores, profissionais da saúde e usuários, considerando as dimensões diálogo, postura e reorganização dos serviços de saúde. Trata-se de uma investigação descritivo-analítica, de natureza qualitativa. Como referencial teórico-metodológico utilizou-se a Teoria Fundamentada nos Dados. Os dados foram obtidos a partir de entrevistas realizadas com sete coordenadores, dez profissionais e doze usuários de Centros de Saúde de Florianópolis-SC. Na perspectiva das boas práticas, o acolhimento converte-se num ponto de intersecção entre diferentes sujeitos e práticas de cuidado na atenção básica à saúde, desdobrando-se nas dimensões acolhimento-diálogo, acolhimentopostura e acolhimento-reorganização dos serviços. O acolhimento desencadeia transformações no processo de trabalho, nas relações estabelecidas nos espaços de cuidado e no âmbito organizacional dos serviços. A interconexão da tríade reconfigura e renova as ações na atenção básica e contribui para a consolidação deste modelo de atenção à saúde.

DESCRITORES: Acolhimento. Atenção primária à saúde. Prática de saúde pública. Sistema Único de Saúde.

\section{ACOGIMIENTO COMO BUENA PRÁCTICA EN LA ATENCIÓN PRIMARIA A LA SALUD}

RESUMEN: Se objetivó comprender el acogimiento como buena práctica de salud en la atención primaria, tras la percepción de gerentes, profesionales y usuarios, teniendo en cuenta las dimensiones diálogo, postura y reorganización de los servicios. Es una investigación descriptiva-analítica, de naturaleza cualitativa y marco teórico-metodológico de la Teoría Fundamentada. Se obtuvieron los datos a partir de entrevistas con siete coordinadores, diez profesionales y doce usuarios de centros de salud de Florianópolis-SC. En vista de las buenas prácticas, el acogimiento se convierte en un punto de intersección entre los diferentes sujetos y las prácticas de cuidado en atención primaria en el desarrollo de las dimensiones acogimiento-diálogo, acogimiento-postura, y acogimiento-reorganización de los servicios. El acogimiento provoca cambios en el proceso de trabajo, en las relaciones establecidas y en la organización de los servicios. La interconexión de la tríada reconfigura las acciones y contribuye a la consolidación de este modelo de atención.

DESCRIPTORES: Acogimiento. Atención primaria de salud. Práctica de salud pública. Sistema Único de Salud. 


\section{INTRODUCTION}

User embracement, or simply embracement, is a concept that is often used to express the relationships established between patients and the professional in health care. However, it does not consist of a simple relationship of service provision. More than that, user embracement implies a humanized and civil relationship consisting of qualified listening. ${ }^{1}$ Based on this concept, the development of embracement as an essential technology for the reorganization of services is characterized as the key element in promoting the effective broadening of access to Primary Health Care (PHC) and to other levels of the system. ${ }^{2}$ Embracement relates, thus, to the bond between the user and the health service, to the solvability of the service and to the adjustment of the service to the user's needs. ${ }^{3}$

The appropriate organization of the services to the environment and culture of the users, respecting their privacy, favors the qualification of provided care and may intervene positively in the health condition of the individual and the collectivity. ${ }^{2-3}$

The National Humanization Policy (NHP) of the Unified Health System (SUS, as per the Portuguese acronym) establishes user embracement as one of the processes constituting the practices of health promotion and production. ${ }^{1}$ Support aspect for the analysis of embracement actions in the PHC may be found in the triad of embracement-dialogue, embracement-attitude and embracementreorganization of the services, comprehended as possible dimensions of embracement. ${ }^{4-5}$

As a combination of dialogical, attitudinal and organizational actions of the care practices in health centers, embracement points out the daily challenge of otherness and may contribute both to the improvement of care practices and to the legitimization of the public health system. . $^{4}$

In the qualification process of the care model, embracement has been configured as one of the main operational guidelines to assure and materialize the SUS principles, particularly those of health care comprehensiveness, universalization of access and equity. It is important to highlight that the proposal of embracement is articulated with other proposals of change in the working process and administration of the health services. Likewise, it is important to understand that the meaning and practice of embracement are comprehensive and inclusive of the most varied fields and processes of health production, which also implicate the production of subjectivities. ${ }^{1}$
In the context of health organizations, good practices are the ones that, through the application of methodological procedures or techniques, have proved reliably to lead to a certain positive result. They are considered good practices because they work in specific contexts and situations, without excessive expense of resources to reach the expected goal. In addition, there is the characteristic of developing solutions adapted to similar health problems in other situations. Good practices gather elements that are proven to contribute to the operation and success of interventions. ${ }^{7}$

It is understood that health actions and services must be adapted to local circumstances, to the target population, to the resources available and to the participants. Hence, good practices in the health area include, in its formulation and development, not only theoretical foundations (scientific evidences), but also the comprehension of the environment and the context in which they are located. They must also consider the beliefs, values and ethical principles of those who build and those who constitute the target audience of the actions and services, focusing on the promotion and improvement of the life and health conditions of the population. ${ }^{8}$

From the perspective of continuous improvement, the guideline of good practices requires permanent reflection on the part of the participants involved in regards to how to improve and intensify the current practices. Thus, it demands the constant analysis of actions developed by the health services, using a critical reflection process regarding what is known to work in a certain situation. Thinking of the action, its purpose and how it could be more effective may guarantee continuous learning and growth through the review of practices. ${ }^{9}$

Based on these perspectives, this study proposes the following study question: what are the meanings and practices that administrators, health professionals and SUS patients attribute to embracement, in considering it a good practice in the BHC context?

Therefore, the purpose of this study was to understand embracement as a good health practice developed in the PHC, in the perception of administrators, health professionals and users, considering the dimensions of dialogue, attitude and reorganization of health services.

\section{METHOD}

This is an exploratory, descriptive and analytical study, with a qualitative nature. The 
theoretical-methodological framework used was the Grounded Theory, which consists of a set of systematic procedures for qualitative data collection and analysis, aimed at building theories based on empirical data. ${ }^{10}$

Data were obtained through individual interviews, performed with seven coordinators of health centers, ten health professionals who work in the Family Health Strategy, 12 patients and six administrators of the health area (city and state level) in Florianópolis-SC. These subjects comprised, respectively, the first, second, third and fourth sample group. ${ }^{10-11}$ Participants were selected to represent the five regional health centers constituting the municipality. Interviews were performed between October 2009 and May 2010.

The speeches were recorded and transcribed, and raw data were examined in order to identify empirical indicators, defined as codes, based on the technique of comparative analysis. In this technique, data are collected and constantly dissected to identify similarities, differences and degrees of consistency, as well as to determine the need to obtain new information. ${ }^{11}$ The software NVivo $8.0 ®$ was used as support for data analysis and organization. The elements of analysis selected for this study contained concepts regarding embracement in its different dimensions as a good practice in health care services, in the context of the PHC, under the perception of administrators, professionals and patients.

The present study is associated with the macro project "Health care system: better organizational practices in the context of public health policies", funded by the Brazilian National Council for Scientific and Technological Development (CNPq). It has been submitted to and approved by the Research Ethics Committee of the Federal University of Santa Catarina (protocol 257/08). Interviewees agreed to participate in the study, after reading and signing the Free and Informed Consent Form.

\section{RESULTS AND DISCUSSION}

\section{Embracement as a good practice in Primary Health Care}

Embracement is considered by all the interviewees to be a good practice in health care. For the coordinators of the health centers, there are many and varied practices that are indicated as being good or better than others. Besides the dif- ferent programs implemented in the PHC scope, there are other practices considered to be good in the routine of the health centers, which contribute to the organization of the working process, such as: adaptation or flexibility of the normative acts to the unit context, matrix support of specialties, and development of home visits and therapeutic or follow-up groups.

The promotion of a bond with patients, through the implementation of embracement practices, scheduling according to coverage area, the active search for cases and the activity of Community Health Agents (CHA) are considered to empower the care directed at the patients' needs. From the view of administrators, listening followed by education provides satisfaction to the patient and solves issues at the moment in which they demand the services of the health center. In this field, the good treatment offered to the client and the positive relationship with the community are valued as they clarify to the patient the routines and procedures, flows and limits of the service.

The good practices identified by the interviewed health professionals also confirm, in some aspects, the view of the administrators; for example, the practice of embracement and the establishment of a bond with the community. There is a displacement of the perception of good practices, originating in more administrative aspects that go towards elements that are more related to facing demands, through a broadening of access and the development of procedures such as vaccines, dressings and appointments.

Patients present similarities with the other groups in terms of understanding embracement as access to health services and actions, good treatment of the patient and a good relationship with the community. Regarding access, patients report they perceive improvements in the availability of appointments and exams, including specialties, and in the decrease in waiting time for appointments.

In some health centers, there is the establishment of negotiation mechanisms with the patients, so that, equally, the involved subjects make decisions regarding urgent cases, prioritization criteria and distribution of appointments. In this sense, the interviewees value service humanization through the encouragement of autonomy, emancipation and communication within the SUS. Under the scope of administration, the participation and flexibility of actions are considered by the coordinators as strategies to adapt to the legal/normative contents to the local reality. 
Under the perspective of good practices, embracement is seen as an intersecting point among different subjects: administrators, health professionals and patients, and different practices in PHC. Study results allow analysis of the meanings of embracement as a good practice under the different studied dimensions: dialogue, attitude and reorganization of the health services.

\section{Embracement in the dialogue dimension}

In terms of the changes triggered in the SUS, one of the most significant is the proposal for a greater integration between professional and patient. Besides establishing bonds and relationships of cooperation and co-responsibility in the consolidation of the system, this integration has spurred the transformation and restructuration of the current communication model, broadening the possibilities for dialogue between health professionals and the patients of the provided services. ${ }^{4,12}$

Dialogue and conversation have been pointed out as the substance of health work. In this sense, the health care network constitutes a network of conversations that permeate all instances of integration between professionals, patients and the flow of care. ${ }^{4,12}$

Embracement-dialogue becomes, thus, a central feature in daily practice, integrating different subjects, articulating different care spaces and broadening the possibilities of traffic through the network. ${ }^{4}$ Consequently, emphasis changes from an instrumental approach to a more relational one, prioritizing the materiality and substantiality of the encounter. Therefore, dialogue is presented as an element of mediation between subjects and the health care network.

Based on this premise, the comprehension of embracement broadens, representing a meeting place between professionals and patients, which refers to both the available physical space for care, and the symbolic space of social relationships and different perceptions and demands of care. ${ }^{13}$

Being a meeting place means, on the other hand, being a place for exercising the otherness, which goes beyond the process of acknowledging the other and their differences, uniqueness and knowledge. Furthermore, it proposes and challenges us to consider the logic of the other, their "point of view" and to legitimize their knowledge, health demands and needs. Moreover, it also challenges us to integrate the voice of the other subject in the processes of choice and decision-making in the daily routine of care practices. ${ }^{6,12-13}$

Nevertheless, it is worth highlighting that the exercise of otherness and the embracementdialogue presupposes a field comprised of tensions, negotiations and conflict management. In this sense, the lack of preparation of professionals, reported by the interviewed patients, besides generating poor service, often triggers intolerant and even aggressive attitudes among professionals and patients.

From the perspective of health professionals and administrators, in order to manage such conflicts the availability of an active, qualified and resolution listening is fundamental, which embraces the other and the references orienting him/her. Therefore, listening to the speech of the person who provides care and the one who receives it is an important factor in making the service feasible and to proceed with the appropriate referral. ${ }^{3}$

Health professionals receive appreciation and acknowledgment of their work through the compliments they receive. Such acts have encouraged good treatment and relationships with patients, which denotes the importance of mutual respect, as pointed out by the professionals, as well as "feeling embraced in order to embrace" ${ }^{\prime 14: 89}$

It is perceived, thus, that collective embracement can re-dimension the meaning of embracement and the meaning of meeting and dialogue as well, establishing and strengthening bonds and reinforcing the credibility of the system and provided services. ${ }^{12}$ Analyzed data showed that the bond between professionals and patients favors dialogue, reinforces relationships of trust, makes the service agile, facilitates compliance with the prescribed treatment and improves the clinical outcomes of patients.

According to the interviewed subjects, this dialogical dimension of embracement represents a differential in primary health care that must be improved through the qualification of professionals and recurrent discussions in monthly planning meetings of the health team.

\section{Embracement in the attitude dimension}

In the analysis of the embracement-attitude dimension there is an understanding that embracement is not an isolated practice, but a set of practices translated into attitudes adopted by both professionals and patients in the interactions 
established in the environment of health services. Embracement-attitude supports, strengthens and gives meaning to the other actions and services performed in the PHC.

Embracement-attitude consists of a proactive manifestation. The incorporation of an embracement attitude includes the service decision in response to the patients' demands, from a verbal orientation to a clinical service. Hence, listening to complaints, fears and expectations; the identification of risks and vulnerabilities; and the act of taking responsibility are actions referring to this dimension.

The interviewed health professionals and administrators believe that they adopt embracement-attitude by questioning the needs identified by the patient and enabling moments of listening, as well as responding to their concerns and wishes with greater qualification. There is evidence that once the service is able to respond to the demands of the patients, there is a higher level of satisfaction felt by both. The attitude adopted by health professionals represents the attitude of the health service itself, constituted as a being.

The relationship established among the service, the professionals and the patients is reciprocal: the way the patient is treated has a direct effect on the way this patient treats the health professionals. Administrators mention that embracement encourages attitudes such as using politeness and manners and lowering the tone of voice, which represents a change in the behavior of patients as they were treated with respect and dignity, and no longer responded with raised voices or were impolite.

Embracement-attitude is capable of strengthening the bond between the service and the patients through the direct acknowledgement of professionals, who have the responsibility to provide individual and community care. The patient identifies the health professional and team with whom he/she has established a bond. In the collective scope, when the service has an attitude of embracement, the community establishes the bond with the health center.

The turnover of professionals harms the establishment of bonds and, consequently, weakens the embracement-attitude. This becomes more evident with the work of CHA and the teams, especially through the quality of the bond created due to the working process in the PHC. The professional knows the patients and calls them by their names. Patients know the professional working in their area and build a feeling of trust with them.
The user's bond with the health service is one of the most valued factors. This bond provides safety to the patients, allowing professionals of the service to know them in order to better establish the priorities in their care. ${ }^{3}$ The bond is also closely related to the need for autonomy/self-care, since by reinforcing the relationship of trust between service and patient it is possible to strengthen the potential for coping with the health-disease process. ${ }^{15}$

In the dimension of embracement-attitude, the services, through their professionals and staff, remain willing to receive the patient and interact with him/her, even if this instance is not associated with the clinical service or procedural intervention. For administrators, it is important to be able to count on a good team of embracing professionals, who assume the patient's care and take responsibility for the resolution of their health problems, proceeding to necessary referrals.

Administrators and professionals highlight the need for qualification and training of all professionals in the practice of embracement. In this sense, reception is the most important sector, since it is often the first contact of the patient with the health service. Patients consider that there are many workers who are poorly prepared to make this first reception contact. Nevertheless, it is important to consider the fact that tensions in the reception area may be higher, due to the population's expectations of care, given that in a unit that provides service the first negative relational impact may compromise the development of the work of the group of qualified professionals. In addition to practicing embracement in the different sectors of the health center, it is necessary to work the embracement conceptually, as a theoreticalhumanistic referential that forms the basis for the relationships between health services and their patients. Embracement, as a relational technology, cannot prescind the training of workers to humanize care, promoting the execution of all activities comprising it and considering the satisfactions of users. ${ }^{16}$

Health professionals and the staff of the SUS, in general, adopt the embracement-attitude by informing users regarding the health services, as well as how the system operates. Once the patient has been educated, reactions of misunderstanding and anger are avoided. It is observed by administrators that educating patients regarding the operation of the services, their rules, criteria and routines has a good effect on the acceptance 
of the difficulties experienced and limitations of the system. Although embracement represents the acknowledgment of the right to health, at times in practice there is failure to execute this constitutional guarantee. An ethical reflection is necessary regarding the situations and problems inherent in the daily routine of providing basic services in order to overcome limitations, re-evaluate attitudes and effectively build new practices in health care. ${ }^{17}$ Embracement-attitude contributes to the democratization of knowledge in the sense of acknowledging health as a civil right. On the other hand, there is still the challenge for Family Health Strategy (FHS) professionals to overcome the monopoly of the diagnosis of needs, broadening the idea of bond construction and responsibility. ${ }^{18}$

The development of embracement-attitude seems to result from the satisfaction felt by PHC professionals in performing their tasks with technical quality, skill and pleasure, serving the patient. According to administrators, the population sees, acknowledges and speaks out regarding the efforts of the professionals. In the case of a professional from the medical area, embracement-attitude is related to the concept of good treatment when this professional not only treats, but also examines, touches, listens to and sees the user.

Embracement-attitude is understood by professionals to be an important element of the social support network, which has a direct influence on the health of people and the community. The practice of home visits is also recognized by professionals as promoting a relationship of trust with the family, and from the family towards the health team. The result of this type of action makes the patient feel comfortable and respected in his/ her individuality.

Professionals reinforce that the attitude dimension of embracement depends on the quantity of professionals available, and even on the appropriate physical space. The good relationship among colleagues, respect among professionals of the team and attention to the internal interprofessional demands are understood as constituting the attitude dimension of embracement. Relational technologies indicate the need for respect, emotional relationships at work, solvability in the service, access to information among team members and among they and the patients, and respect in the process of health production. ${ }^{16}$

The readiness of universal access to the services, with agility and promptness, is considered by the professionals to be an element of the embracement-attitude. Although the focus is still maintained on the main complaint of the patients, on appointments or exams, embracementattitude refers to a view of the patient as a whole, not only as a procedure. Patients intensely value embracement-attitude as a means of access to the services, considering it good quality whenever their needs are met. Therefore, service in the form of appointments, emergencies or administration of medication, which results in a response to their demands, is positively evaluated. This perception, despite not being similarly understood by the health professional inserted in the SUS, constitutes a legitimate demand, often interpreted as a clientelist (patron-client) form of care or reinforcement of the biomedical model.

\section{Embracement in the dimension of reorganiza- tion of health services}

This last category considers embracement in the organizational and political scopes, in a predominantly administrative field. The expressions of this dimension comprise embracement both in the sense of an internal organization of the system and the health care policy, and in the sense of following the legal principle of the right to health.

The reorganization of health services, the qualification of provided care and the facilitation and broadening of access to care are actions aimed at assuring civil participation in the public health system. As a technology in the relationship with health actions, this theme considers the need for respect and emotional relationships at work, problem-solving in the service and access to information among team members and among they and the patients. ${ }^{16}$

All interviewed groups emphasize embracement-reorganization of services as a response to the demand for problem-solving. Paradoxically, a quick response with quality can also generate a waiting line, since good service, easy access to care, and available appointments and exams may lead patients from other locations to use the services of the health center. The differentiated care provided to the patients involves the comprehension of the care model, including the operation of the system planned with the FHS, both by health professionals and administrators, and by the system users (patients). Administrators and professionals understand that the principles and guidelines of the NHP favor new action strategies, which allow a greater bond with the community. However, 
some principles are divergent; for instance, the territorialization or assigning clients to a specific region as opposed to providing universal access, complicating embracement in this dimension of service reorganization. Hence, professionals and administrators understand the need for balance and common sense in the observation of normative requirements; that is, common sense in the interpretation of guidelines.

The question of embracing patients based on a technical strategy of reception, triage and referral goes against the discourse of an ideal embracement resulting from the principles of the NHP. Administrators and employees understand the embracement process as a premise of the new health care model; however, they may disagree on the rhetoric of the right to health and the practice of not following this constitutional guarantee. ${ }^{17}$

From the point of view of the internal organization of the service, embracement-reorganization is emphasized from the exercise of planning, considering either a collegiate or local autonomous administration, with technical-operational support from regional and central levels. According to the interviewees, the location and geographic access to the health center, availability of the appropriate physical space and sufficient capacity of installation are structural elements that facilitate access. Besides these, the provision of resources, logistic support, articulation between local services and care programs, access to the information system and availability of electronic records are also considered subsidies for the development of good embracement-reorganization.

Constituting a dimension with a strong administrative component, this embracement dimension includes two sets of requisites: the first one associated with the management of people; and the second related to the development of action strategies. Regarding the management of people, embracement-reorganization is acknowledged when there is a committed team whose dynamics are established under the principle of comprehensiveness. Professionals and patients emphasize the need for a sufficient number of doctors. From the perspective of access, embracement and bonding, there is a great demand for clinical treatment in the health services and a reduced number of doctors to provide this service ${ }^{19}$, although the purpose and operation method of the FHS is still to be consolidated.

This strategy, as one more challenge of the health system, is ambiguous in the sense of aiming to strengthen the focus on health promotion and supervision; at the same time there is a reduced number of professionals in some areas with an intense demand for health services. According to administrators and professionals, low professional turnover, the ability to provide embracement and available appointments promote the strengthening of the bond and access to care. In the words of the professionals, embracement is perceived when they are referred by people in their coverage area.

Regarding the action strategies, the interviewees emphasize the operation of embracement through the organization of schedules. These include efficient operations in the reception area, care provided according to scheduled and spontaneous demand, and meeting the urgent needs of people in each area in a timely fashion. In this perspective, embracement-reorganization becomes a channel of reflection and communication, resulting from the agility of the supply of matrixed or specialized actions and services, home visits and actions of the CHA.

Embracement, as an operational technology, is considered to be in the development stage and may vary in terms of levels of conception and strategies of work routine reorganization. The extension of the basic network has contributed to improving geographic accessibility, but there is still a disproportion among supply, service capacity and demand, which generates discontinuity in care and in the access to referrals. ${ }^{20}$

It is important to consider that an efficient and embracing service may have access difficulties due to an expressed demand from other locations that find, in this service, the means to treatment. The local supply of some sort of specialty can also generate external demands and complicate the bond with those who do not reside in the territory of the health centers.

In the perception of health professionals, the development of systematic technical meetings contributes to standardizing the service and strengthens professional commitment. The creation of spaces for therapeutic groups and a contribution network for the patient's comprehensive care, in addition to the restructuring of the team for the development of external actions, are strategies that promote embracement-reorganization.

The embracement-reorganization of the services, according to patients, responds to service quality (good or poor), scheduling of appointments, reductions in waiting times, streamlining of the system of form distribution and the prefer- 
ential service provided to certain groups, such as children. The main factors valued by the patients are the bond of the patient with the health service and the professional performance of the person who provides care. ${ }^{2-3}$

\section{FINAL CONSIDERATIONS}

In the process of consolidation of the health care model, reorganization of care practices and service quality, embracement has been viewed as a contributive guideline to the materialization of the SUS principles. In the perspective of good practices, embracement becomes an intersection point among different subjects and care practices in the PHC. It is represented through the good treatment and relationship with the community and listening followed by instruction/education and yields different dimensions, such as the ones presented in this study: dialogue, attitude and reorganization of healthcare services.

The dialogical dimension of embracement has represented a differential in primary health care. The search for a greater integration between professional and patient has supported the transformation of the current communication model. Embracement-dialogue becomes a central dimension in healthcare work, whether as a factor of mediation between subjects or as a factor of articulation between different fields of health production. It emphasizes, thus, a more relational approach, prioritizing the meeting and exercise of otherness.

Embracement is not an isolated practice, but a set of practices translated into attitudes that people adopt in the interactions established in the environment of health services. Embracementattitude consists of a proactive manifestation, capable of strengthening the bond of the service with the patients through the direct acknowledgement of professionals, who have the responsibility to provide individual and community health care. The development of embracement-attitude seems to result from the satisfaction felt by PHC professionals in carrying out their tasks. Patients value it as an access mechanism, praising the service whenever their needs are satisfied.

Embracement in the dimension of reorganization of the health services, situated in a predominantly administrative field, expresses both the internal organization of the system and the health care policy, in addition to the exercise of a civil participation in the public health system.
Embracement-reorganization has prerequisites, such as the strategic management of people and actions, which results in an effective channel of communication between service and patient, as well as in the efficiency of the supply of actions and services through a team with strong professional commitment. Some situations stand out due to the fact that they presented inconsistencies, whether regarding principles, conflicts in the operation of care, or in the relationship between health care quality and excessive demand, which is often directly proportional. Nevertheless, the comprehension regarding this health care model under development stands out as imperative for carrying out a differentiated and embracing care model.

Embracement, in its different dimensions, triggers transformation in the working process, in the relationships established in the care spaces and in the organizational scope of the services. The interconnection of the triad embracement-dialogue, embracement-attitude and embracement-reorganization of services reconfigures and promotes change; thus, the actions in the PHC have the purpose to implement the humanization policy in the SUS and consolidate its health care model.

\section{REFERENCES}

1. Ministério da Saúde (BR). Secretaria de Atenção à Saúde. Núcleo Técnico da Política Nacional de Humanização. Acolhimento nas práticas de produção de saúde. Brasília (DF): MS; 2010.

2. Ramos DD, Lima MADS. Acesso e acolhimento aos usuários em uma unidade de saúde de Porto Alegre, Rio Grande do Sul, Brasil. Cad Saúde Públ. 2003 Jan-Fev; 19(1):27-34.

3. Lima MADS, Ramos DD, Rosa RB, Nauderer TM, Davis R. Acesso e acolhimento em unidades de saúde na visão dos usuários. Acta Paul Enferm. 2007 Jan-Mar; 20(1):12-17.

4. Teixeira RR. O acolhimento num serviço de saúde entendido como uma rede de conversações. In: Pinheiro R, Mattos RA, organizadores. Construção da integralidade: cotidiano, saberes e práticas em saúde. Rio de Janeiro (RJ): IMS/UERJ/Abrasco; 2005. p. 89-111.

5. Silva Júnior AG, Mascarenhas MTM. Avaliação da atenção básica em saúde sob a ótica da integralidade: aspectos conceituais e metodológicos. In: Pinheiro R, Mattos RA, organizadores. Cuidado: as fronteiras da integralidade. Rio de Janeiro (RJ): IMS/UERJ / Abrasco; 2006. p. 241-57.

6. Scholze AS, Duarte Junior CF, Flores e Silva, Y. Trabalho em saúde e a implantação do acolhimento na atenção básica à saúde: afeto, empatia ou 
alteridade? Interface - Comunic Saúde Educ. 2009 Out-Dez; 13(31):303-14.

7. Organização Mundial da Saúde (OMS). Guia para a Documentação e Partilha das "Melhores Práticas" em Programas de Saúde. Escritório Regional Africano Brazzaville: OMS, 2008. [acesso $2011 \mathrm{Jul}$ 10]. Disponível em: http://afrolib.afro.who.int/ documents/2009/pt/GuiaMelhoresPratica.pdf

8. Kahan B, Goodstadt M. The interactive domain model of best practices in health promotion: developing and implementing a best practices approach to health promotion. Health Prom Practice. 2001 Jan; 2(1):43-67.

9. Nova Scotia Health Department. A framework for a best practices approach to health promotion. Second version [online]. Canadá: 2002. [acesso 2011 Set 12]. Disponível em: http://www.hpclearinghouse.ca/ downloads/framework.pdf.

10. Charmaz K. Constructing grounded theory: a practical guide through qualitative analysis. London (UK): Sage Publications; 2007.

11. Glaser B. Grounded theory perspective III: theoretical coding. Chicago (US): Sociology Press; 2005.

12. Cavalcante Filho JB, Vasconcelos EMS, Ceccim RB, Gomes LB. Acolhimento coletivo: um desafio instituinte de novas formas de produzir o cuidado. Interface: Comun Saúde Educ. 2009 Dez; 31(13):315-28.

13. Santos M. A natureza do espaço: técnica e tempo, razão e emoção. São Paulo (US): Editora da Universidade de São Paulo; 2002.
14. Schneider DG, Manschein AMM, Ausen MAB, Martins JJ, Albuquerque GL. Acolhimento ao paciente e família na unidade coronariana. Texto Contexto Enferm. 2008 Jan-Mar; 17(1):81-9.

15. Moraes PA, Bertolozzi MR, Hino P. Percepções sobre necessidades de saúde na Atenção Básica segundo usuários de um serviço de saúde. Rev Esc Enferm USP. 2011 Mar; 45(1):19-25.

16. Coelho MO, Jorge MSB. Tecnologia das relações como dispositivo do atendimento humanizado na atenção básica à saúde na perspectiva do acesso, do acolhimento e do vínculo. Ciênc Saúde Coletiva. 2009 Set-Out; 14(Sup.1):1523-31.

17. Brehmer LCF, Verdi M. Acolhimento na atenção básica: reflexões éticas sobre a atenção à saúde dos usuários. Ciênc Saúde Coletiva. 2010 Nov; 15(3):3569-78.

18. Gomes MCPA, Pinheiro R. Acolhimento e vínculo: práticas de integralidade na gestão do cuidado em saúde em grandes centros urbanos. Interface [online]. 2005 Mar-Ago [acesso 2011 Jul 12]; 9(17):287-301. Disponível em: http://dx.doi. org/10.1590/S1414-32832005000200006

19. Coelho MO, Jorge MSB, Araújo ME. O acesso por meio do acolhimento na atenção básica à saúde. Rev Baiana Saúde Pública. 2009 Jul-Set; 33(3):440-52.

20. Souza ECF, Vilar RLA, Rocha NSPD, Uchoa AC, Rocha PM. Acesso e acolhimento na atenção básica: uma análise da percepção dos usuários e profissionais de saúde. Cad Saúde Pública. 2008; 24(Sup 1):S100-10. 